\title{
き裂先端近傍における圧縮残留応力場の形成過程に関する研究*
}

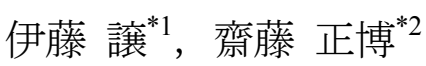

\section{A Study on the Forming Process of the Compressive Residual Stress Field around the Crack Tip}

\author{
Yuzuru ITO ${ }^{* 1}$ and Masahiro SAITO \\ ${ }^{* 1}$ Hachinohe Inst. of Tech. Dept. of Mechanical Engineering \\ 88-1, Myo, Obiraki, Hachinohe, Aomori, 031-8501 Japan
}

It would be possible to understand the mechanism for forming a compressive residual stress field around the crack tip by measuring the stress directly. It would also be possible to contribute to the construction of a crack growth model that enables us to explain a retardation effect on crack growth. In this study, the process of the forming a compressive residual stress field around the crack tip caused by overloading was examined using the X-ray diffraction method. In order to examine the effect of overloading, the stress intensity factor of $30 \mathrm{MPa} \sqrt{ } \mathrm{m}$ was applied to the specimen, which $K=25 \mathrm{MPa} \sqrt{\mathrm{m}}$ had been applied. The measured stress near the crack tip after the overloading was reduced to by $23-44 \%$ in comparison with before the overloading was applied. Through this experimental approach, a formation of the compressive residual stress field around the crack tip as well as the effect of the overloading on a stress reduction was revealed.

Key Words : X-Ray, Stress Measurement, Residual Stress, Crack, Over Loading, Fracture Mechanics

\section{1. はじめに}

圧力容器等は水圧試験による安全検査が行われるが，これは容器強度向上に役立つとされている．たとえば溶 接欠陥のようなき裂が存在する延性部材にあらかじめ引張力を付加すると，き裂端に著しい応力集中が起こり， 降伏する，そして，き裂先端部が塑性変形して開き，これがある限界值（き裂開口変位，COD）に達するとき裂 は伝播して破断する．このような大きな変位を起こさせない範囲で除荷すると，き裂先端の塑性変形部に圧縮力 が残留する ${ }^{(1)}$. 実際に破壊力学試験片を用いた実験によると，過大荷重の負荷・除荷というプロセスを経たき裂 先端近傍には圧縮残留応力場が形成されると報告(2)されている。こうしたき裂を含む部材等への過大荷重負荷の 効果としては, 疲労き裂進展速度 ${ }^{(3)}$ や応力腐食割れ（SCC）進展速度(4)の一時的な低下, 見かけの応力腐食割れ下 限界応力拡大係数 $K_{I S C C}$ の大幅な向上 ${ }^{(5)}$ があったとの報告がある.

過大荷重前後のき裂先端近傍における応力場を直接評価することは，き裂を含む部材における圧縮残留応力場 形成の現象をより正確に掌握，理解できるとともに，過大荷重により疲労き裂進展速度や応力腐食割れ進展速度 の低下を具体的に説明可能なき裂進展モデルの構築に寄与できると考えられる，そこで，本研究では，き裂先端 近傍に圧縮残留応力場が形成される過程を，X線応力測定法 ( $\sin ^{2} \psi$ 法) を用いて実験的に評価する. 代表的な鋼 種としてオーステナイト系ステンレス鋼 SUS304，および炭素鋼 S45C の 2 種類を選定し，それぞれ過大荷重の負 荷・除荷によるき裂先端近傍の圧縮残留応力場形成の過程を明らかにすることを目的とする.

\footnotetext{
* 原稿受付 2012 年 9 月 22 日

*1 正員, 八戸工業大学（广031-8501 青森県八戸市大字妙字大開 88-1) (現 日本アドバンストテクノロジー(株))

*2 正員, 八戸工業大学 工学部 機械情報技術学科

E-mail: yuzuru@hi-tech.ac.jp
} 


\section{2. 実験方法}

\section{$2 \cdot 1$ 供試材および試験片}

市販の SUS304 鋼，および S45C 鋼を供試材として使用した。それぞれの化学組成と機械的特性を表 1 にまと めて示す. なお, SUS304 鋼の降伏応力は $0.2 \%$ 耐力を, S45C 鋼の降伏応力は下降伏点の值を示した. 本研究で使 用した供試材 SUS304 鋼と S45C 鋼は，ともに引張強さが降伏応力の 1.3 倍以上となる約 2.4 倍（SUS304 鋼）ま たは約 1.8 倍（S45C 鋼）であり，高い加工硬化を示寸材料であった.

試験片には，定変位での応力腐食割れ試験 ${ }^{(6)}$ に用いられるWOL（Wedge Opening Load）試験片 (7)を用いた．本 研究で使用した WOL 試験片の形状を図 1 に示寸. 本研究では, SUS304 鋼, およびS45C 鋼ともに基準とする応 力測定時の荷重を $25 \mathrm{MPa} \sqrt{\mathrm{m}}$ とした. そこで, 疲労予き裂導入時の $K$ 值は $K=25 \mathrm{MPa} \sqrt{\mathrm{m}}$ の $80 \%$ となる $K=20 \mathrm{MPa} \sqrt{\mathrm{m}}$ とした．疲労予き裂長さは，機械加工によるスリットから 0.5 1.0 mm とした.

\section{$2 \cdot 2$ 応力測定方法}

応力測定装置には Proto 社製の i-XRD を使用した. 表 2 に応力測定条件をまとめて示す. SUS304 鋼および S45C 鋼の両鋼種ともに，管電圧と管電流はそれぞれ $20 \mathrm{kV} ， 4 \mathrm{~mA}$ に設定した.コリメータ（絞り）は は1.0のものを用 いた．本研究のすべての応力測定において，WOL 試験片表面のき裂進展方向に対して垂直な方向の応力を測定 した.

\section{$2 \cdot 3$ 試験片表面の研磨}

\section{$2 \cdot 3 \cdot 1$ 表面残留応力除去の効果の確認}

本研究では, 製作した試験片の応力除去焼鈍しを省略した. ただし, 試験片の応力測定領域には機械的な研磨 処理を施すことにより, 主として試験片の製作過程で発生した表面残留応力を除去した. 疲労予き裂の導入後, \#320 \#1 500 の研磨紙と，\#6 \#1 のダイヤモンドペーストをそれぞれ用いて表面を研磨した。 これらの研磨処理に よる表面残留応力除去の効果を確認するため, 一連の応力測定に供した WOL 試験片とは別の WOL 試験片を用 いた予備実験を実施した．なお，予備実験の応力測定条件は表 2 と同一であり，かつ疲労予き裂の導入過程で発 生した塑性域を避けるため, き裂先端部から $4 \mathrm{~mm}$ 以上離れた領域を測定した.

\section{2・3 2 SUS304 鋼の予備実験結果}

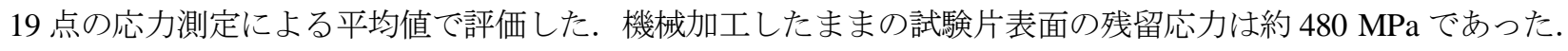
ここから, 研磨紙 1500 までの研磨, 続いてダイヤモンドペースト\#1までの研磨により, それぞれ約 $77 \mathrm{MPa}$, 約 $48 \mathrm{MPa}$ の試験片表面の応力值を得た. したがって, 研磨紙\#1 500 までの研磨でおよそ 87\%, 続くダイヤモン ドペースト\#1 までの研磨でおよそ 90\%の残留応力を除去することができた. SUS304 鋼については, 研磨紙\#1 500 までとダイヤモンドペースト\#1までの研磨を両方実施することで十分と判断した.

\section{$2 \cdot 3 \cdot 3 \mathrm{S45C}$ 鋼の予備実験結果}

4 点の応力測定による平均值で評価した. 機械加工したままの試験片表面の残留応力は約 $347 \mathrm{MPa}$ であった. SUS304 鋼と同様の要領で, 研磨紙\#1 500 までの研磨, 続いてダイヤモンドペースト\#1までの研磨により, それ ぞれ約-225 MPa, 約-113 MPa の試験片表面における応力值を得た. 研磨により圧縮側の忘力值となったものの, 応力 0 を基準に絶対值で評価すれば，研磨紙 1500 までの研磨によりおよそ 35\%，ダイヤモンドペーストの研磨 によりおよそ 67\%の残留応力を除去できたと考えられる. しかし，SUS304 鋼に比して効果的に表面残留応力を 除去できなかったため, S45C鋼については電解研磨を施すことにした. その効果の確認のため, ダイヤモンドペ ーストで研磨した面を電解研磨したところ, およそ $97 \%$ 残留応力を除去することに成功し, このときの応力值 は約 $9 \mathrm{MPa}$ であった，ただし，WOL 試験片のき裂部を電解研磨する際には，研磨液がき裂の隙間に浸透しない ように予めマニキュアでき裂をシールしてから電解研磨を施した。 
Table 1 Chemical compositions and Mechanical properties

Chemical compositions [wt\%]

Mechanical properties

\begin{tabular}{|c|c|c|c|c|c|c|c|c|c|c|c|c|}
\hline & C & Si & Mn & $\mathbf{P}$ & $\mathbf{S}$ & $\mathbf{N i}$ & $\mathrm{Cr}$ & $\mathrm{Fe}$ & $\sigma_{\mathrm{y}}[\mathrm{MPa}]$ & $\sigma_{\mathrm{B}}[\mathrm{MPa}]$ & $\sigma_{\mathrm{f}}[\mathrm{MPa}]$ & Elong. \\
\hline SUS304 & 0.04 & 0.52 & 0.91 & 0.030 & 0.001 & 8.07 & 18.16 & Bal. & 262 & 639 & 451 & $60 \%$ \\
\hline S45C & 0.49 & 0.18 & 0.63 & 0.014 & 0.019 & - & - & Bal. & 376 & 701 & 539 & $21 \%$ \\
\hline
\end{tabular}

Table 2 X-ray setting conditions

\begin{tabular}{rlc}
\hline & SUS304 & S45C \\
\hline Characteristic X-ray & Mn-K $\alpha$ & Cr-K $\alpha$ \\
Diffraction line & $311, \gamma-\mathrm{Fe}$ & $211, \alpha-\mathrm{Fe}$ \\
Bragg angle, $2 \theta_{0}$ & $152.80[\mathrm{deg}]$ & $156.31[\mathrm{deg}]$ \\
$\sin ^{2} \psi$ range & \multicolumn{2}{c}{$0 \sim 0.445,9$ points } \\
Tube voltage and current & $20[\mathrm{kV}], 4[\mathrm{~mA}]$ \\
Irradiated area & $\phi 1[\mathrm{~mm}]$ \\
\hline
\end{tabular}
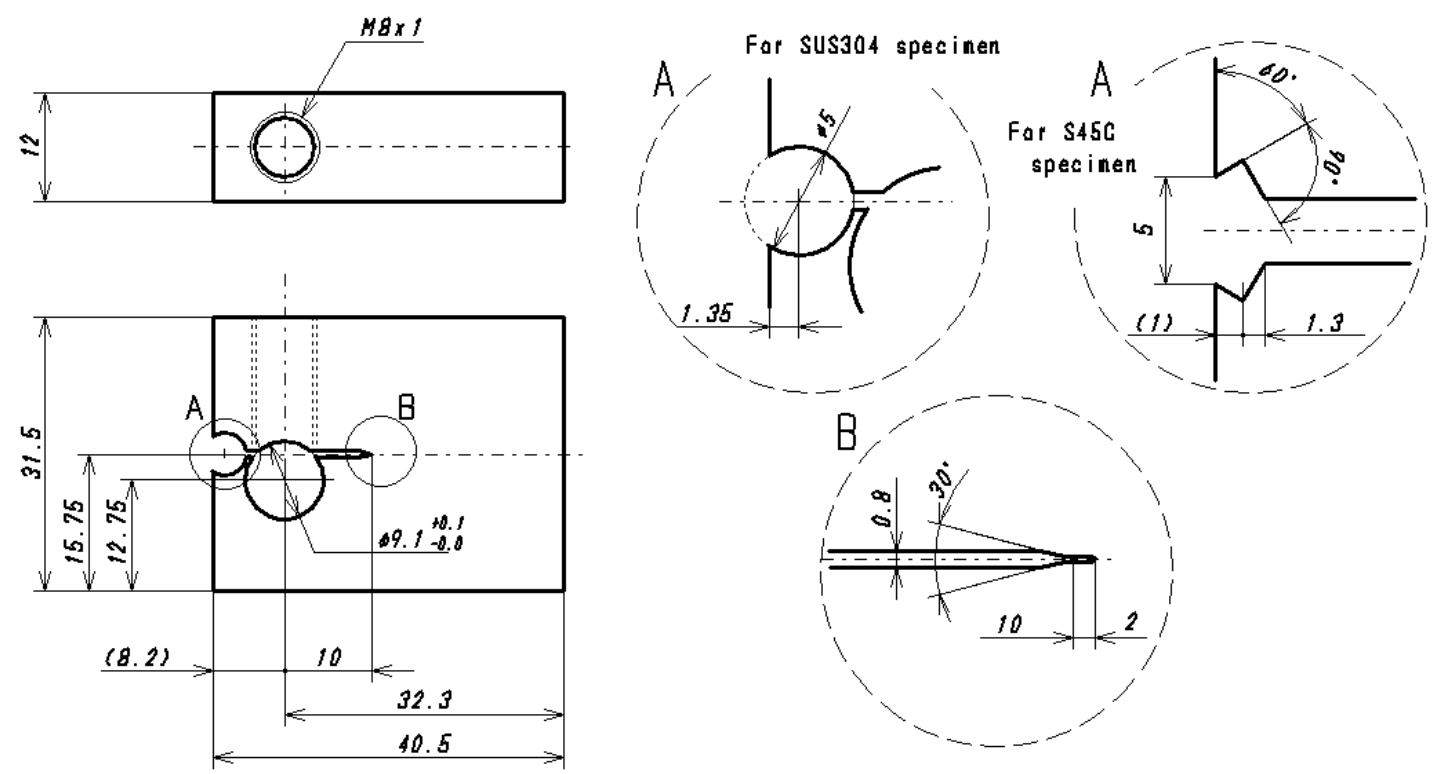

Fig. 1 Specimen geometry of the WOL specimen.

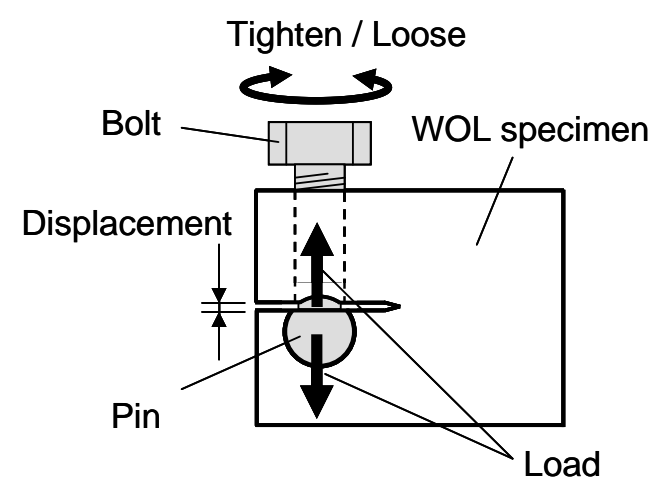

Fig. 2 Setup of the WOL specimen and its fixtures.

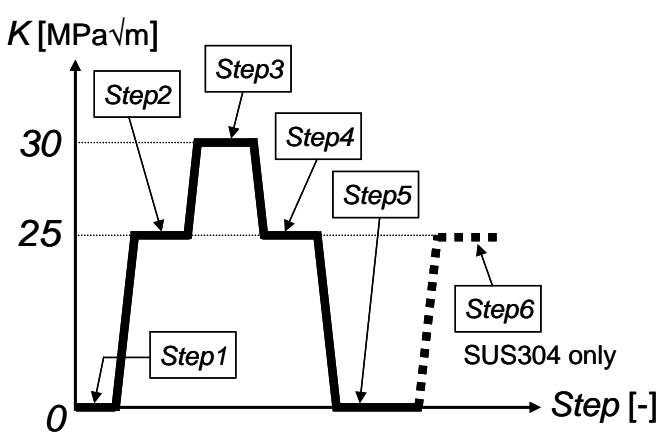

Fig. 3 Loading sequence for the WOL specimen. 


\section{$2 \cdot 4$ 荷重負荷条件}

WOL 試験片は, 図 2 に示すようにボルトを締めることで荷重負荷, 逆に緩めることで除荷が可能である，そ して図 3 の手順に従い, WOL 試験片に荷重を負荷する前（Step 1）の状態から，K=25 MPa $\sqrt{\mathrm{m}}$ 負荷時（Step 2）, $20 \%$ 過大荷重となる $K=30 \mathrm{MPa} \vee \mathrm{m}$ 負荷時（Step 3)，K=25 MPa $\sqrt{\mathrm{m}}$ 除荷時（Step 4), 完全除荷後（Step 5）の計 5 段階にて WOL 試験片の応力を測定した。ただし，SUS304 鋼については，完全除荷した Step 5 に続いて再度 $K=25 \mathrm{MPa} \sqrt{\mathrm{m}}$ を負荷した段階（Step 6）を追加した. 荷重負荷時および除荷時には, WOL 試験片を応力測定装置 のステージから取り外して荷重負荷ボルトを回転させた。なお，各 Stepにおける応力測定で WOL 試験片をステ ージに取り付ける際は，き裂先端の位置を基準の座標として毎回位置決めを行い，応力測定点が常に一致するよ うにした。

\section{$2 \cdot 5$ 応力測定範囲}

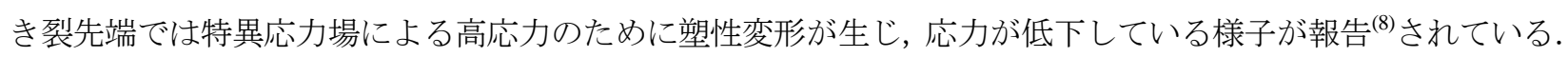
そこで，き裂先端部を基点として，そこから塑性域外部の弾性域までを連続的に測定した。文献を界を参考に，両 鋼種の $K=30 \mathrm{MPa} \vee \mathrm{m}$ 負荷時における平面応力状態の塑性域寸法を試算すると，式（1）および式（2）に示すよう に SUS304 鋼で約 $4.2 \mathrm{~mm}$, S45C 鋼で約 $2.0 \mathrm{~mm}$ であった，そこで，両鋼種ともに，き裂先端部からき裂が進展す る方向に沿って $8 \mathrm{~mm}$ までの領域を測定した. ただし, 両鋼種の塑性域寸法の違いを考慮して, SUS304 鋼の場合 は $2.0 \mathrm{~mm}$ 間隔， $\mathrm{S} 45 \mathrm{C}$ 鋼の場合は $0.5 \mathrm{~mm}$ 間隔でそれぞれ測定した.

$$
\begin{aligned}
& \omega_{\mathrm{SUS} 304}=2 \cdot r_{P}=2 \cdot\left(\frac{1}{2 \pi}\right) \cdot\left(\frac{K}{\sigma_{y}}\right)^{2}=\left(\frac{1}{\pi}\right) \cdot\left(\frac{30 \times 10^{6}}{262 \times 10^{6}}\right)^{2} \approx 4.17 \times 10^{-3}[\mathrm{~m}] \\
& \omega_{\mathrm{S} 45 \mathrm{C}}=2 \cdot r_{P}=2 \cdot\left(\frac{1}{2 \pi}\right) \cdot\left(\frac{K}{\sigma_{y}}\right)^{2}=\left(\frac{1}{\pi}\right) \cdot\left(\frac{30 \times 10^{6}}{376 \times 10^{6}}\right)^{2} \approx 2.03 \times 10^{-3}[\mathrm{~m}]
\end{aligned}
$$

\section{3. 実験結果}

\section{$3 \cdot 1$ SUS304 鋼}

図 4(a)に，荷重を負荷する前（Step 1）から完全除荷後（Step 5)，および再負荷（Step 6）までの応力測定結果 を示す. 式 (1) で求めた塑性域寸法は $\omega_{304}=4.2 \mathrm{~mm}$ であり, き裂先端部から $6 \mathrm{~mm}$ および $8 \mathrm{~mm}$ の位置は弾性変 形した領域の測定結果であったと考えられる. 特に, き裂先端部から $6 \mathrm{~mm}$ の位置における測定值は, Step 1 Step 5 を通してほぼ一定の約-70 MPa であった，これは，弾性変形した領域であったこと，および測定位置の位置決め が毎回適切であったことが反映されたものと考えられる. また, き裂先端部が圧縮の応力となったのは, 試験片 に荷重を負荷していない状態の荷重負荷前（Step 1）と完全除荷後（Step 5）だけであった. Step 5 の応力值は約 -116 MPa であり, Step 3 の 20\%過大荷重を経験したにもかかわらず, Step 1 の応力值, 約-108 MPa に対して約 $8 \mathrm{MPa}$ だけ圧縮側の值となった. そこで Step 6 として再度 $K=25 \mathrm{MPa} \sqrt{\mathrm{m}}$ を負荷したところ, き裂先端部の応力值 は約 $87 \mathrm{MPa}$ となり, Step 4 時（過大荷重を除荷したとき）の応力値, 約 $125 \mathrm{MPa}$ よりもさらに小さな応力值で あった。

\section{$3 \cdot 2 \mathrm{~S} 45 \mathrm{C}$ 鋼}

図 4(b)に，荷重を負荷する前（Step 1） から完全除荷後（Step 5）までのすべての応力測定結果を示す.なお, Step 1 のみ $2.0 \mathrm{~mm}$ 間隔で測定した. 式（2）で求めた塑性域寸法は $\omega_{545 \mathrm{C}}=2.0 \mathrm{~mm}$ であり, き裂先端部から $2 \mathrm{~mm}$ を超える位置は弾性変形した領域の測定結果であったと考えられる. 荷重負荷時となる Step 2 Step 4 の, き裂先 端部から 2 5 mm の位置における測定結果はほぼ一致している.これは, SUS304 鋼の結果と同様に, 弾性変形 した領域であったこと，および測定位置の位置決めが毎回適切であったことが反映されたものと考えられる. 


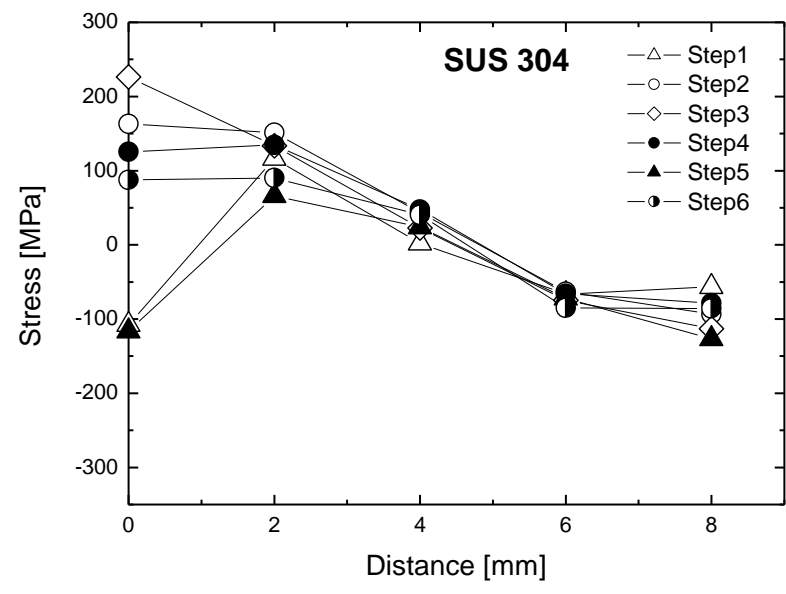

(a)

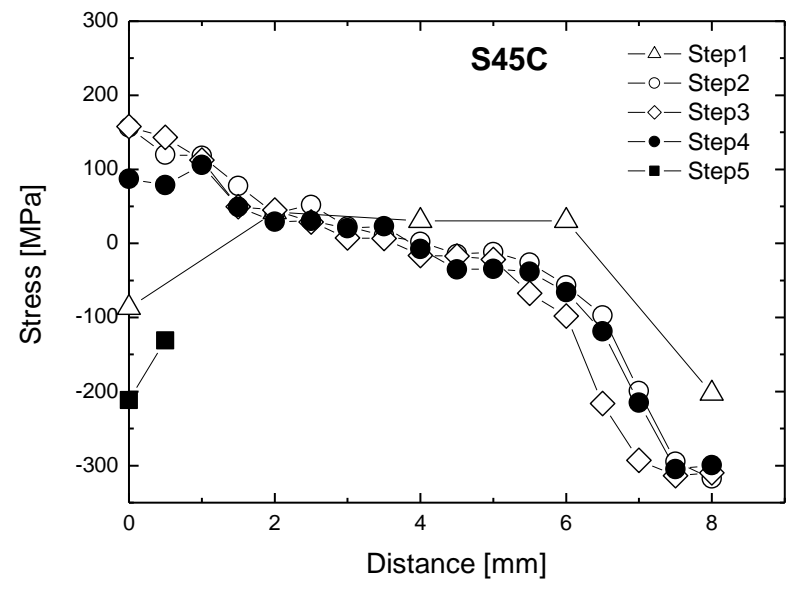

(b)

Fig. 4 The variation of the measured stress along the crack growth direction, (a) in SUS304, (b) in S45C.

S45C 鋼においては，完全除荷後（Step 5）の測定中，装置不具合によりき裂先端部近傍の 2 点しか測定できなか った．よって，限られたデータではあるものの，き裂先端部が圧縮の応力となったのは，やはり SUS304 鋼の結 果と同様，試験片に荷重を負荷していない状態の荷重負荷前（Step 1）と完全除荷後（Step 5）だけであった。し かし, S45C 鋼のStep 5 においては, Step 1 における測定值の約-87 MPa に比して大幅な圧縮側となった約-211 MPa であった.

\section{4. 考 察}

\section{$4 \cdot 1$ 過大荷重負荷の効果}

\section{4・1・1＼cjkstart荷重を引き続き負荷したままのとき}

図 4(a)および図 4(b)の，K=25 MPa $\sqrt{m}$ 負荷時（Step 2）から過大荷重負荷中（Step 3）を含めて除荷時（Step 4） までの段階における応力值の変化を抜き出した結果を図 5(a)および図 5(b)に示す. SUS304 鋼および S45C 鋼につ いて, 過大荷重負荷を含む Step 2 Step 4 の一連の操作によってき裂先端部には圧縮残留応力が付加されているの が観察できた．才なわち，荷重を完全に除荷しなくても，過大荷重の効果を得ることができたと考えられる．た だし，その効果が得られる範囲は，塑性域寸法内のき裂先端部に極めて近い限られた領域であった。 図 6 には, $K=25 \mathrm{MPa} \vee \mathrm{m}$ 負荷時（Step 2）に測定された応力值を基準として, $K=25 \mathrm{MPa} \sqrt{\mathrm{m}}$ 除荷時（Step 4）の塑性域寸法内 における応力值の低減率を示寸，同図には文献(2) の炭素鋼 SM400B の值を引用し，低減率を整理した結果も合わ せて示した，その結果，過大荷重の負荷・除荷によりき裂先端近傍の応力值は，SUS304 鋼にて 163 MPa から $125 \mathrm{MPa}$ の約 23\%，S45C 鋼にて $157 \mathrm{MPa}$ から $87 \mathrm{MPa}$ の約 44\%それぞれ低減していた. ゆえに，本研究では， 20\%の過大荷重の負荷・除荷によって, き裂先端部近傍の応力值が過大荷重負荷前の 23 44\%低下したことから, き裂先端近傍の圧縮残留応力場形成の過程を明らかにすることができた.

\section{$4 \cdot 1 \cdot 2$ 完全に除荷したとき}

荷重を負荷する前（Step 1）に測定された応力值を基準として，完全除荷後（Step 5）のき裂先端近傍における 応力值の変化を図 7(a)および図 7(b)に示す.その結果, S45C 鋼では一連の荷重負荷により圧縮残留応力が負荷前 の約 2.4 倍となり, 過大荷重負荷の影響が顕著に現れた. 文献(2)でも同様な傾向が得られており, Step 1 相当のき 裂先端近傍の応力值，約-6 MPa が，完全除荷後には約-199 MPa となっている. 一方，SUS304 鋼ではその影響 がほとんど観察されず，完全除荷後は約 $8 \mathrm{MPa}$ だけ圧縮側の值となった。本研究の S45C 鋼, および文献)の SM400B 鋼では過大荷重負荷の影響が顕著に現れており, SUS304 鋼にて観察されなかった原因の解明が必要である. 


\section{$4 \cdot 1 \cdot 3$ 再び荷重を負荷したとき}

完全除荷時に過大荷重負荷の影響が SUS304 鋼では顕著に現れなかった原因を解明すべく, Step 5 に続いて再 度 $K=25 \mathrm{MPa} \sqrt{\mathrm{m}}$ を負荷した段階（Step 6）を追加して過大荷重負荷の効果を評価した. 図 5(a)より, Step 6 ではき 裂先端部の応力值が約 $87 \mathrm{MPa}$ となった. 寸なわち, Step 4 時の応力值, 約 $125 \mathrm{MPa}$ よりもさらに小さな応力値 となり, 結果として過大荷重の効果は荷重履歴の進展とともに圧縮応力の付加が明確に現れたと考えられる.

ここで，完全除荷時に過大荷重負荷の影響が顕著に現れなかった原因の一つとして，K=20 MPa $\sqrt{\mathrm{m}}$ の疲労予き 裂導入による荷重履歴の影響が挙げられる．き裂先端部にすでに圧縮残留応力場が形成されていたため, 1 回の $K=30 \mathrm{MPa} V \mathrm{~m}$ 負荷で新たに形成された圧縮残留応力は約-8 MPa 分であったとも換言できる. すなわち， S45C 鋼 やSM400B 鋼と SUS304鋼では $K=25 \mathrm{MPa} V \mathrm{~m}$ の 20\%過大荷重で得られる圧縮残留応力の効果が異なると考えられ る. しかしながら, 疲労予き裂導入時の $K=20 \mathrm{MPa} V \mathrm{~m}$ 以上の荷重を負荷した条件, 具体的には過大荷重負荷時と その前後の Step 2 Step 4 で測定された応力值の比較は, 疲労予き裂による残留応力の影響を小さくできると考え られる. したがって, 本研究では, 20\%の過大荷重の負荷・除荷によって, き裂先端部近傍の応力値が過大荷重 負荷前の 23 44\%低下したことから，き裂先端近傍の圧縮残留応力場形成の過程を明らかにすることができた.

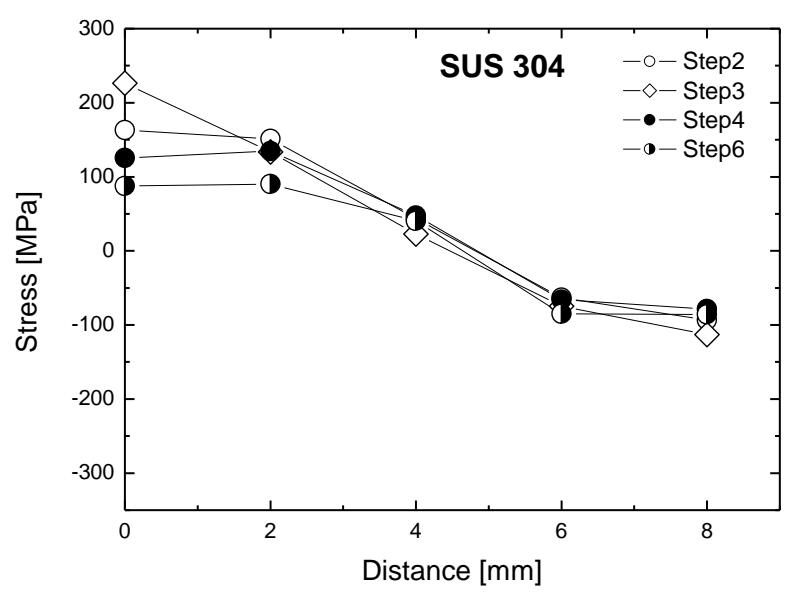

(a)

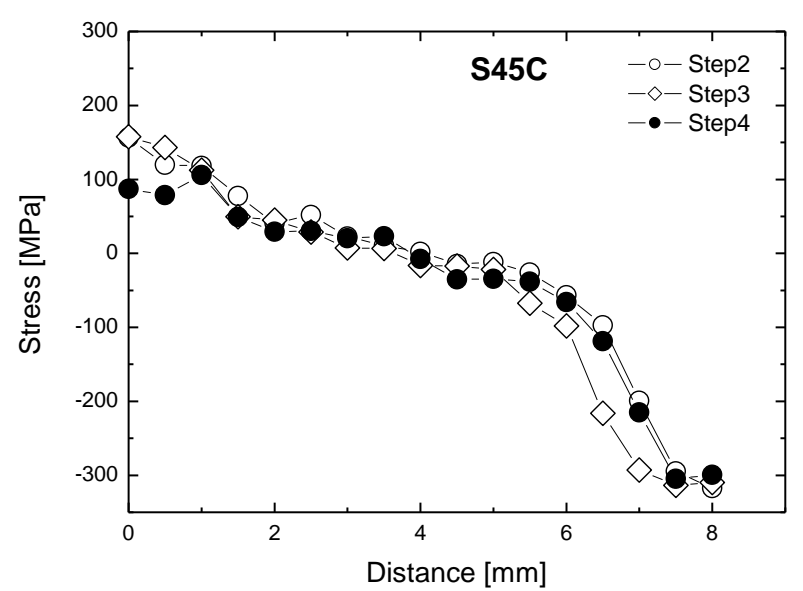

(b)

Fig. 5 The variation of the measured stress before, during and after the overload applied, (a) in SUS304, (b) in S45C.

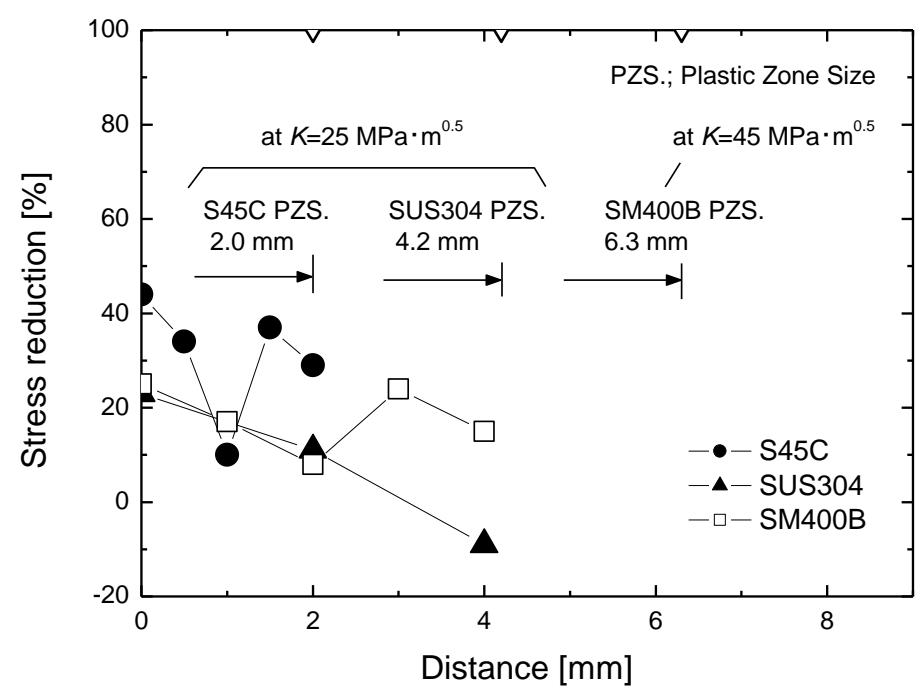

Fig. 6 The comparison of the stress reduced after the overload applied in SUS304, S45C and SM400B ${ }^{(2)}$. 


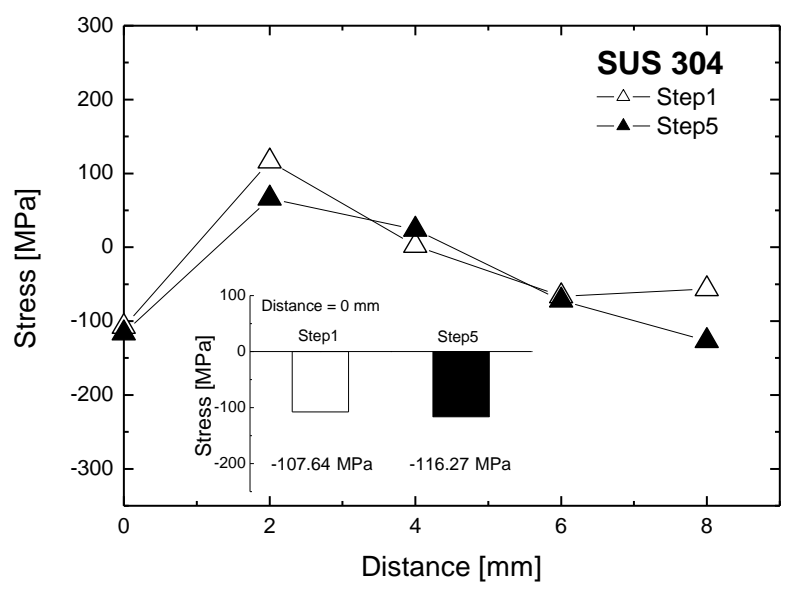

(a)

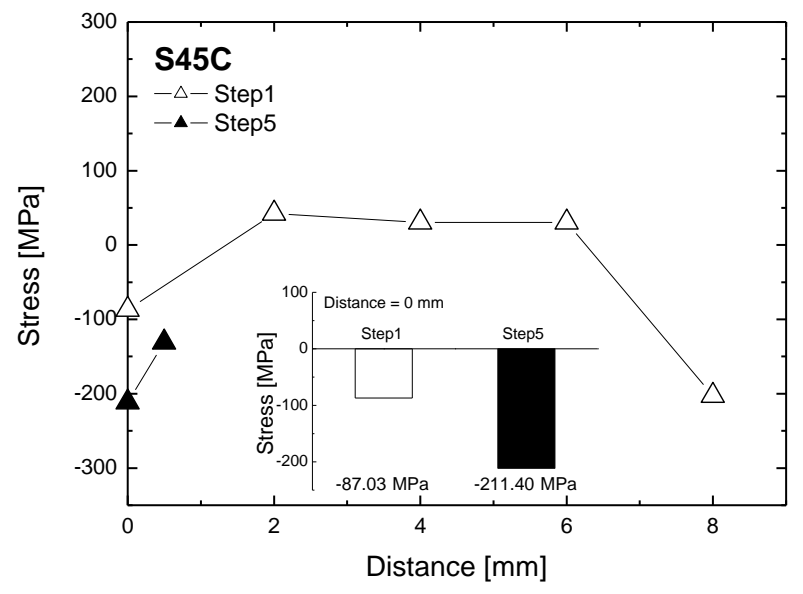

(b)

Fig. 7 The variation of the measured stress before, during and after the overload applied, (a) in SUS304, (b) in S45C.

\section{$4 \cdot 2$ 応力分布を有する領域での測定について}

き裂先端部には応力分布が存在する．したがって，本研究では，応力が連続的に変化した領域をコリメータ径 （応力測定した領域）で区切り，その領域内の平均的な応力值を測定していたと考えられる．そこで，応力分布 の無い応力值がほぼ 0 の標準試料と, 応力分布を有する WOL 試験片のき裂先端近傍を, $\phi 0.5$ と $\phi 1.0$ の 2 種類の コリメータ径でそれぞれ測定した，測定に供した WOL 試験片はSUS304 鋼であり，本研究の Step 1 Step 5 およ びStep 6 の測定に供した WOL 試験片である.ただし，Step 6 の後に除荷しており，測定時は完全除荷状態であ った．応力測定条件は表 2 と同一である．それぞれの試験片の測定部について，標準試料については，試験片の 中央部 $1 \mathrm{~mm} \times 1 \mathrm{~mm}$ の領域を 4 点測定し, その平均值を求めた。一方, WOL 試験片については, き裂先端部から き裂が進展する方向に沿って $8 \mathrm{~mm}$ までの領域を $1.0 \mathrm{~mm}$ 間隔で測定した. その結果を図 8(a)および図 8(b)に示寸. WOL 試験片のき裂先端部等の測定結果は若干異なるものの, それ以外の領域, および標準試料の測定結果は, 両コリメータ径で測定した応力值はほぼ一致した。

一方，き裂先端近傍の弾性変形状態を解く理論式から計算されるき裂先端近傍の応力分布を求め, その領域を $\phi 1.0$ のコリメータ径で測定した場合に得られる応力值を推算した. 理論式には式 (3) を使用し， $K=30 \mathrm{MPa} \sqrt{\mathrm{m}}$ で $\theta=0^{\circ}$ (き裂進展方向）の応力分布を計算した. ただし, 塑性域内の応力はほぼ降伏応力になるはず(10)として, き 裂先端部から式（1）および式（2）で得られる $r_{P}$ (平面応力状態の塑性域寸法の $1 / 2$ ) までは両鋼材の降伏応力 の值とした. こうして求めた期待される応力分布を基に, 式 (4) で表現するような, 期待される応力分布のうち $\phi 1.0$ のコリメータ径で区切られる区間の平均の応力值を求め, これを式 (5) のように差 $d$ として評価した. そ の結果を図 9(a)および図 9(b)に示す. 期待される応力分布から得られる応力值と式 (4) で表現する平均值, 寸な わち期待される応力の測定值との差は, SUS304 鋼で最大約 $2.7 \%$, S45C 鋼で最大約 $5.0 \%$ であた. したがって, $\phi 1.0$ のコリメータで応力測定した結果は, 理論式から期待される応力の測定值に対して高々 $5 \%$ の違いと推定される.

$$
\begin{aligned}
& \sigma_{y y}=\frac{K_{\mathrm{I}}}{\sqrt{2 \pi r}} \cos \frac{\theta}{2}\left(1+\sin \frac{\theta}{2} \sin \frac{3 \theta}{2}\right) \\
& \sigma_{\mathrm{yy} \text { Ave. }}=\text { (期待される応力分布のうち } \phi 1.0 \text { のコリメータ径で区切られる区間の平均の応力值) } \\
& d=\frac{\left|\sigma_{y y \text { Ave. }}-\sigma_{y y}\right|}{\sigma_{y y}} \times 100
\end{aligned}
$$




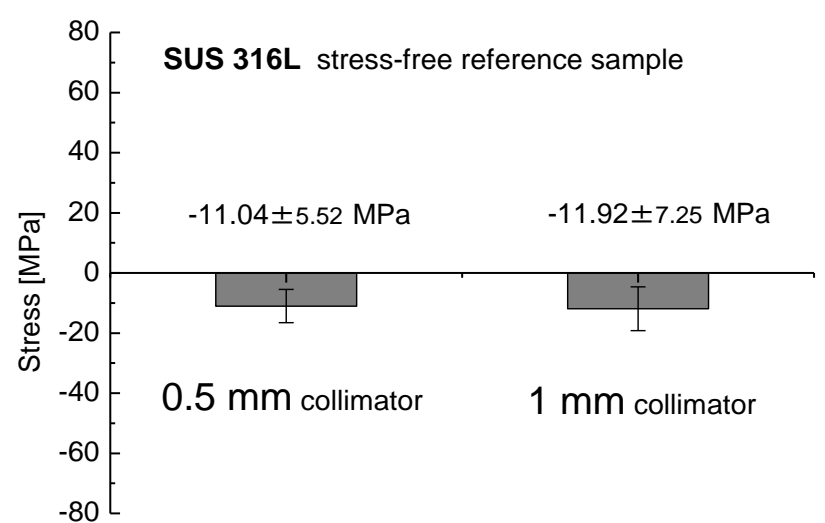

Collimator size

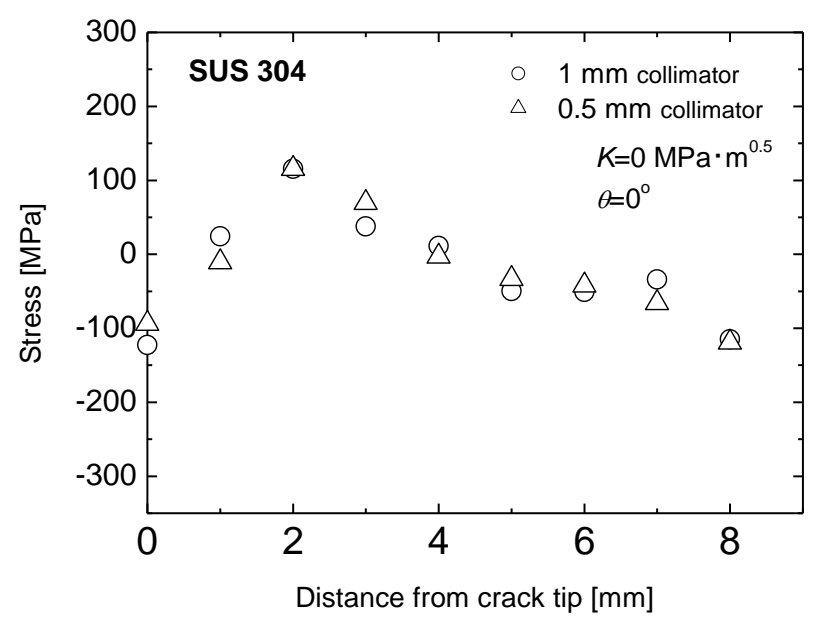

(b)

Fig. 8 Confirmations of the measured value by stress-free reference sample and the comparison the measured stress between $\phi 1$ and $\phi 0.5$ collimators.

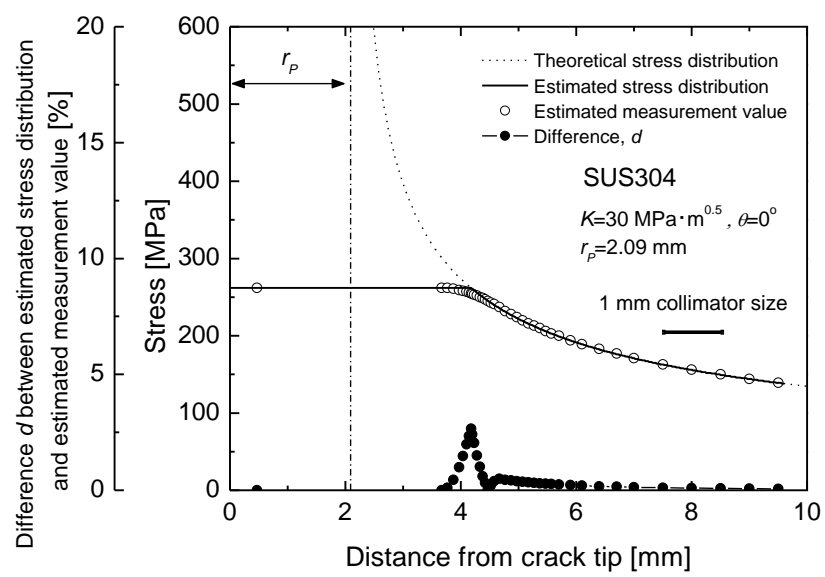

(a)

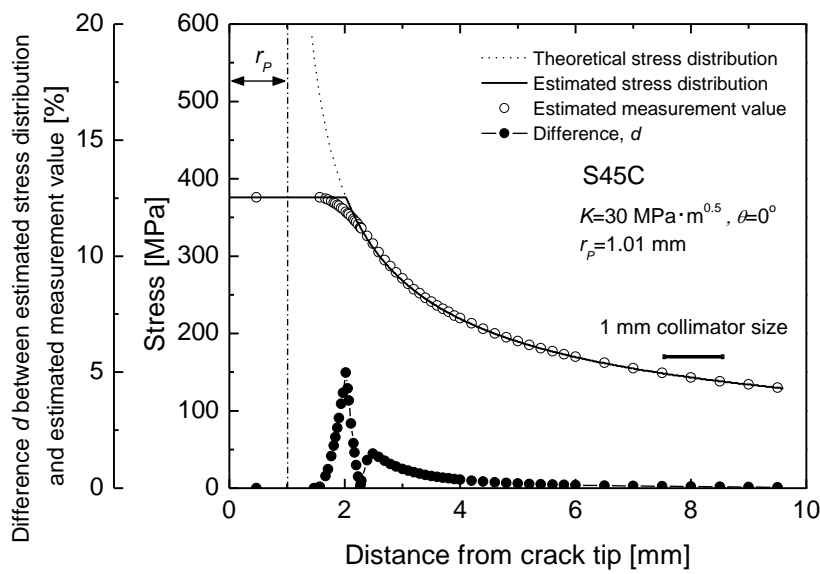

(b)

Fig. 9 The comparison between estimated stress distribution and estimated measurement value with the collimators.

\section{$4 \cdot 3$ 測定された応力値の定量性}

ただし，図 4(a)および図 4(b)の Step 3（過大荷重負荷中）で測定された応力值は，図 9(a)および図 9(b)に示した 期待される応力の測定值（降伏応力）に対して，SUS304 鋼で約 14\%，S45C 鋼で約 58\%低かった。したがって, 測定值の降伏応力に対する定量性に関する議論はあるものの，過大荷重の負荷・除荷に伴うき裂先端部における 残留応力場の形成過程を定性的に評価できたと考えられる。ゆえに，本研究は定性的な評価ではあるが，図 6 に よると，過大荷重の負荷・除荷によって S45C 鋼で約 44\%，SUS304 鋼で約 23\%の応力値の低下をき裂先端部に て観察しており，その過大荷重負荷の効果に関してはほぼ定量的な評価ができたものと考えられる.

\section{5. まとめ}

本研究では, き裂先端近傍に圧縮残留応力場が形成される過程を, X 線応力測定法を用いて実験的に評価した. その結果, $K=20 \mathrm{MPa} V \mathrm{~m}$ の $20 \%$ 過大となる荷重の負荷・除荷によって, き裂先端部の応力值は $\mathrm{S} 45 \mathrm{C}$ 鋼で約 44\%, 
SUS304 鋼で約 23\%の低下をそれぞれ確認した，すなわち，過大荷重を経験した後のき裂先端近傍には，荷重を 完全に除荷しなくても圧縮残留応力の効果を得ることができることを明らかにした.

また，測定結果の定量性の検討から， $\phi 1.0$ のコリメータで応力測定した結果は，理論式から期待される応力の 測定值に対して高々5\%の違いであったと考えられる.ただし，期待される応力值（降伏応力）に対して, SUS304 鋼で約 14\%，S45C 鋼で約 58\%低かった。したがって，測定值の降伏応力に対する定量性に関する議論はあるも のの，過大荷重の負荷・除荷に伴うき裂先端部における残留応力場の形成過程を定性的には評価できたと考えら れる. ゆえに，定性的な評価ではあるが，本研究では過大荷重の負荷・除荷によってき裂先端部での応力の低下 を観察し，その過大荷重負荷の効果に関してはほぼ定量的な評価ができたものと考えられる.

\section{謝 辞}

本研究は, 八戸工業大学 工学部 機械情報技術学科の卒業研修として, 平成 22 年度の柏谷一樹 氏, 大高勇人氏, 三田祐樹 氏, 工藤隆太 氏, 森 健吾 氏による研究の成果, および平成 23 年度の佐藤知範 氏, 高舘和弥 氏, 板橋 翼氏, 坂田 陸 氏, 谷川博紀 氏による研究の成果を基に, 論文としてまとめたものである.

\section{文献}

（1）須藤 一, “残留応力とゆがみ”, 第3 版 (2003), 内田老鶴围, p. 109.

（2）伊藤 譲, 澤頭孝幸, 木村慎吾, 齋藤正博, 鈴木賢治, “き裂先端近傍における圧縮残留応力場の形成に関する実験的検討”, 日本材料学会 第 44 回X線材料強度に関するシンポジウム講演論文集，2010年 7月 8-9 日, pp. 85-90.

（3）幡中憲治，石川雄寿，“き裂先端近傍のひずみ計測に基づく単一過大荷重による疲労き裂進展の遅延現象の検討”， 日本機械学会論文集 A 編，Vol.59，No.567 (1993)，pp. 2531-2539.

(4) Yuzuru ITO, Masahiro SAITO, Qunjia Peng, Jiro KUNIYA, Tetsuo SHOJI, "Influencing Factors for Improving Accuracy in Prediction of Stress Corrosion Crack Growth Rate in Boiling Water Reactor Operational Condition -2, - The Effect of Single Overload on SCC Growth Behavior -", Proceedings of the ASME 2010 Pressure Vessels \& Piping Division / K-PVP Conference, July 18-22, 2010, Bellevue, Washington, USA, Paper ID. PVP2010-26121.

(5) 佐野勇人, 高橋宏治, 安藤 柱, “過大予荷重効果によるステンレス鋼の応力腐食割れの阻止”, 日本機械学会論 文集 A 編，Vol.77，No.773 (2011)，pp. 218-222.

（6）例えば, 伊藤 譲, 齋藤正博, “応力腐食割れ進展挙動に及ぼす単一過大荷重負荷の影響”, 日本機械学会 M\&P2009 講演論文集, 2009 年 11 月 5-7 日, 講演番号 526.

（7）日本材料強度学会, 応力腐食割れ標準試験法一日本学術振興会第 129 委員会基準一, pp. 8-17, (1985).

（8）田中啓介，鈴木賢治，秋庭義明，“残留応力の X 線評価”，第 1 版，p. 165，(2006)，養賢堂.

（9）岡村弘之，“線形破壞力学入門”, 初版, p. 78, (1976), 培風館.

（10）岡村弘之, “線形破壊力学入門”, 初版, pp. 77-78, (1976), 培風館. 